\title{
IbM PENERAPAN BIOTEKNOLOGI DAN PENGOLAHAN LIMBAH MEDIA TANAM JAMUR MERANG DI KECAMATAN NISAM KABUPATEN ACEH UTARA
}

\section{IbM IMPLEMENTATION OF BIOTECHNOLOGY AND STRAW MUSHROOM MEDIA'S WASTE TREATMENT IN NISAM SUBDISTRICT NORTH ACEH DISTRICT}

\author{
Oleh: \\ Zuriani, Rosnina, Martina \\ Fakultas Pertanian, Universitas Malikussaleh \\ Email: zuriani@unimal.ac.id
}

\begin{abstract}
The cultivation of mushroom in Nisam Subdistrict is constrained by several factors, such as the limited ability of biotechnology breeding and cultivation, marketing and capital. After harvesting, planting media left without any further processing. Moreover, partner farmers has obstacles in terms of marketing and capital limitations for business development. Mushroom cultivation activity was doing by a farmer group "Jamur Nismara" and a farmer group "Tani Jamur" had to stop since the end of 2014 as a consequence. Activities devotion aims to revive the activities of mushroom cultivation that has been there with the technique of better management. The goal to be achieved is a group of reliable and independent farmers. Therefore, the farmers should have knowledge and skills about biotechnology of mushroom cultivation starting from breeding, making the ideal kumbung, correct the cultivation process and processing of planting media waste into compost fertilizer which have an economic value. Farmers must have the ability to access information, especially related to marketing. The methods used are counselling and direct implementation / practice by involving all group members. The results are farmers have kumbung and cultivation ability, marketing, and processing waste media. In addition, farmers also have knowledge about nursery technology.
\end{abstract}

Keywords: mushroom, biotechnology, cultivation, waste media planting

\section{PENDAHULUAN}

Jamur merang merupakan salah satu jenis sayuran yang bernilai ekonomis tinggi. Oleh karena itu, usaha budi daya jamur merang sangat cocok diusahakan, baik dalam skala kecil maupun skala besar. Namun demikian, mengusahakan jamur merang bukan tanpa kendala, dibutuhkan lokasi yang sesuai, teknik budidaya yang benar, serta bibit yang berkualitas. Selain itu, Kelembaban udara juga merupakan faktor yang paling berpengaruh dalam pertumbuhan jamur. Umumnya kelembaban udara yang dibutuhkan sekitar 80-90\% (Asep, 2013). Jamur merang dikenal dengan warm mushroom, hidup dan mampu betahan pada suhu relatif tinggi, antara $30^{\circ} \mathrm{C}-38^{\circ} \mathrm{C}$, dengan suhu optimum $35^{\circ} \mathrm{C}$ (Wiardani, 2010).

Jamur merang merupakan jenis sayuran yang sehat untuk dikonsumsi. Jamur merang memiliki kandungan protein mencapai 1,8 persen, lemak 0,3 persen, dam karbohidrat 12 - 
48 persen (Sinaga, 2015). Berdasarkan kandungan gizi yang dimiliki oleh jamur merang maka sangat pantas jika dikatakan bahwa jamur merang merupakan sumber nutrisi dan protein dengan harga yang lebih murah sebagai pengganti protein hewani.

Petani jamur di Gampong Meunasah Rayeuk Kecamatan Nisam mulai melakukan budidaya jamur merang pada tahun 2009. Pada saat itu, sistem pemasaran yang dilakukan oleh petani adalah dengan menitipkannya kepada tukang sayur langganan mereka yang ada di pasar-pasar tradisional di Kota Lhokseumawe. Tahun 2014, tepatnya bulan Desember usaha jamur merang berhenti budidaya karena mengalami kerugian. Tahun 2016, petani jamur merang berniat untuk membangkitkan kembali usaha mereka. Namun niat mereka terkendala oleh berbagai faktor salah satunya keterbatasan modal. Dengan modal yang sangat terbatas mereka berusaha memastikan bahwa usaha jamur yang akan mereka rintis kembali tidak akan rugi. Salah satu upaya yang mereka lakukan untuk memastikannya adalah dengan meminta kembali tukang sayur untuk menjadi penjual jamur mereka. Namun ternyata, sebagian besar tukang sayur langganan mereka dulu sekarang sudah menerima pasokan jamur dari wilayah mereka sendiri yaitu Kota Lhokseumawe. Selain itu, masalah kelangkaan bibit juga menjadi pelengkap kekhawatiran para petani untuk kembali melakukan budidaya jamur merang yang dulu pernah mereka lakukan. Masalah kelangkaan bibit merupakan masalah yang dialami oleh semua petani jamur yang ada di Kabupaten Aceh Utara dan Kota Lhokseumawe (Tassan, 2016). Bibit jamur yang baik untuk dibudidayakan adalah bibit yang memiliki nilai BER (Biological Efficiency Ratio) yang tinggi. Untuk mendapatkan bibit yang berkualitas maka proses pembuatan bibit harus dilakukan dengan penuh ketelitian dan dalam kondisi steril (Sunarmi dan Cahyo, 2013).

Fenomena sesungguhnya adalah jamur merang merupakan sayuran yang digemari oleh semua orang. Sebagian besar masyarakat Aceh sangat menggemari jamur merang apalagi jika dijadikan sebagai pelengkap masakan seperti mi instan. Saat ini permintaan jamur merang di Aceh mengalami peningkatan sedangkan jumlah produksi mengalami penurunan (Una, 2016). Jadi, sebenarnya jamur merang itu masih merupakan barang yang agak langka di Aceh, khususnya Kabupaten Aceh Utara. Hanya diperlukan sedikit cara dan upaya untuk memasarkan, maka jamur merang akan jadi primadona. Oleh karena itu, kekhawatiran para petani untuk tidak membudidayakan jamur merang karena takut tidak terjual bukan alasan yang ilmiah.

\section{METODE PENGABDIAN}

Kegiatan $\mathrm{IbM}$ dilaksanakan dengan menggunakan beberapa metode yang disesuaikan dengan luaran yang ditargetkan. Metode tersebut terbagi sebagai berikut:

\section{Workshop Pembibitan, Budidaya, Pemasaran dan Pembuatan Pupuk Kompos}

Bengkel (workshop) dilaksanakan bertujuan memberikan pengetahuan dan ketrampilan kepada petani jamur merang mitra binaan tentang ilmu yang bersifat teoritis dalam pelaksanaan dan hal yang berkaitan teknik pembibitan, budidaya, dan pemasaran jamur merang. Workshop yang dilaksanakan pada awal kegiatan ini diharapkan dapat menjadi bekal para petani jamur merang binaan dan mampu mengatasi permasalahan yang timbul dalam pelaksanakan budidaya dan pemasaran jamur merang.

Pada kegiatan ini nanti akan ditayangkan slide tentang cara pembibitan, dan budidaya jamur merang secara konvensional yang sudah terbukti keberhasilannya. Hal ini diharapkan dapat membantu petani dalam memperbaiki dan meningkatkan keterampilan yang sebelumnya menyebabkan kegagalan dalam pelaksanaan budidaya jamur merang. Terkait dengan pemasaran, petani akan diberikan materi tentang tata cara pemasaran jamur 
merang yang baik serta pemasaran online. Selain itu, kegiatan ini bertujuan untuk membekali mitra tentang tata cara pembuatan pupuk kompos dari limbah media tanam jamur merang. Petani mitra akan diberikan tutorial tentang teknik pengomposan limbah media tanam jamur merang yang baik dan benar.

\section{Penerapan/ Praktek}

Setelah memberikan pembekalan sacara materi maka dilanjutkan dengan mempersiapkan bahan dan alat kerja baik untuk pembuatan kumbung, pasteurisasi dan material sebagai media tanam jamur merang. Setelah semua perlatan dan bahan tersedia maka akan dilakukan penerapan langsung yang melibatkan petani binaan sebagai bentuk pelatihan bagi petani mitra. Berikut penerapan yang dilakukan:

- Pembuatan bibit jamur merang

- Pembuatan kumbung yang kondusif

- Pembuatan media tanam.

- Pasteurisasi media tanam

- Penaburan benih (spawning)

- Perawatan/pemeliharaan

- Pemanenan yang tepat

- Pembuatan pupuk kompos dari limbah media tanam jamur merang.

- Pelatihan Penggunaan media sosial sebagai sarana pemasaran online

Kegiatan ini bertujuan untuk melihat kemampuan petani binaan dalam mengaplikasikan teori yang sudah diberikan melalui workshop.

\section{Evaluasi}

Pada akhir pelaksanaan program penerapan bioteknologi dan pengolahan limbah jamur merang akan dilakukan evaluasi. Kegiatan evaluasi dilakukan dengan cara membandingkan proses pelaksanaan dengan materi yang diberikan pada saat workshop. Apabila terdapat perbedaan maka akan dilakukan penyesuaian dan akan dicari solusi jika terjadi permasalahan. Selain itu, evaluasi juga dilakukan dari aspek finansialnya.

Setelah kegiatan penerapan dilaksanakan, petani akan dibina/ dibimbing secara berkelanjutan. Dalam pelaksanaan budidaya jamur merang, para petani jamur ini akan dibimbing dan dipantau secara reguler (kunjungan $4 \mathrm{kali} / \mathrm{siklus} \mathrm{budidaya} \mathrm{jamur} \mathrm{merang).}$ Pemantauan (monitoring) secara reguler ini diharapkan dapat mengatasi permasalah yang terjadi dan dapat memperlancar proses budidaya serta memperoleh produksi jamur merang seperti yang diharapkan. Pada akhirnya petani jamur binaan dapat menjadi mitra mandiri yang handal dan mampu menerapkan bioteknologi jamur merang dalam mengelola usaha budidaya jamur merang berbasis bioteknologi yang berkonsep nol limbah (zero waste) dan bersifat komersial.

\section{HASIL DAN PEMBAHASAN}

Pengabdian IbM Penerapan Bioteknologi dan Pengolahan Limbah Media Tanam Jamur Merang di Kecamatan Nisam Kabupaten Aceh Utara ini telah dilaksanakan sejak bulan Mei 2017. Adapun kegiatan-kegiatan yang telah dilakukan adalah sebagai berikut:

1. Sosialisasi akan diadakannya kegiatan pengabdian IbM pada kelompok tani jamur oleh tim pengabdian

2. Peninjauan lokasi tempat usaha budidaya jamur pada kedua mitra pengabdian

3. Peninjauan tempat untuk kegiatan penyuluhan/Workshop kepada mitra pengabdian yang berlokasi di rumah ketua kelompok tani jamur Nismara

4. Identifikasi alat dan bahan-bahan yang dibutuhkan oleh mitra pengabdian 
5. Mempersiapkan kegiatan penyuluhan kepada mitra tentang teknik pembibitan, budidaya, pemasaran, dan pengolahan limbah media tanam jamur merang.

6. Melaksanakan kegiatan workshop pengabdian jamur. Kegiatan workshop berupa penyuluhan dilakukan di rumah salah satu ketua kelompok tani, yaitu Tgk. Baha Uddin. Adapun penyuluhan yang dilakukan adalah sebagai berikut:

a. Penyuluhan tentang bioteknologi pembibitan, budidaya jamur merang, dan pengomposan limbah media tanam: Rosnina, S.P., M.P.

b. Penyuluhan tentang pemasaran: Zuriani, S.P., M.P.

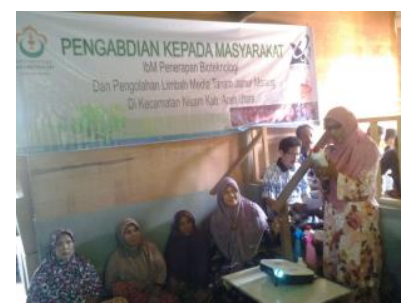

Gambar 1. Kegiatan workshop

7. Memberikan alat-alat yang dibutuhkan oleh mitra pengabdian untuk budidaya jamur seperti bahan dan peralatan pembuatan kumbung, bahan pengomposan media tanam, bibit, kereta sorong, drum, dll.

8. Kegiatan budidaya mulai dari pembuatan kumbung, persiapan media tanam, persiapan kumbung sampai siap tanam, penaburan bibit, pemeliharaan sampai panen.
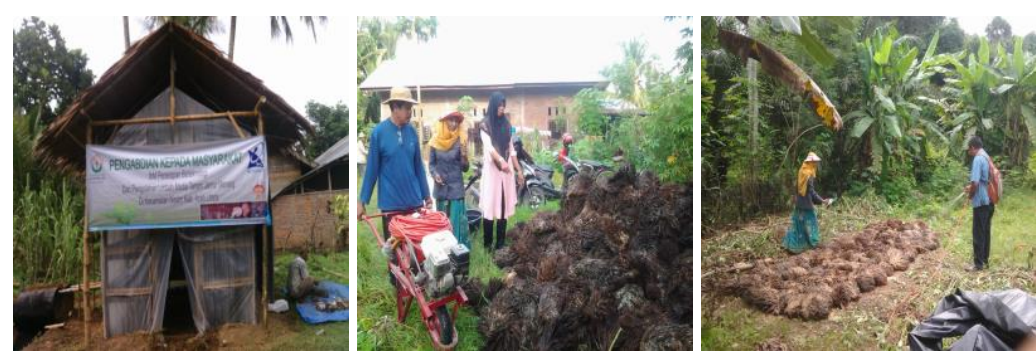

Gambar 2. Salah satu kumbung yang hampir siap pakai, Gambar 3. Persiapan pengomposan, Gambar 4. Kegiatan pengomposan
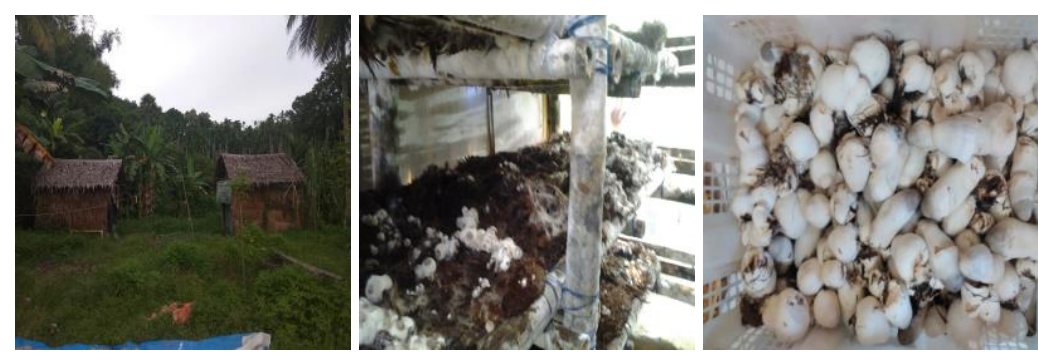

Gambar 5. Kumbung yang siap pakai, Gambar 6. Jamur yang mulai tumbuh, Gambar 7. Jamur hasil panen pertama

9. Kegiatan praktek pembuatan bibit jamur merang dilakukan di laboratorium Fakultas Pertanian Universitas Malikussaleh. Petani mitra melihat dan terlibat langsung pada saat proses pembuatan bibit. Proses pembibitan yang dilakukan gagal di tengah jalan. Bibit mengalami kontaminasi menjelang proses inokulasi sehingga gagal tumbuh. 


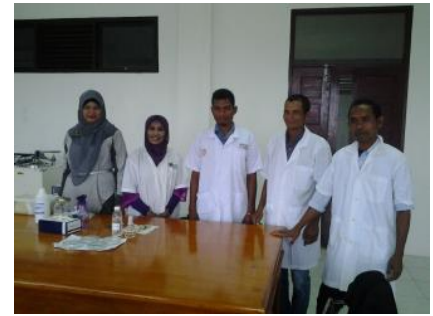

Gambar 8. Petani mitra belajar pembibitan di laboratorium

10. Kegiatan terakhir dari program ini adalah pembuatan pupuk kompos dari limbah media tanam. Kegiatan ini dilakukan setelah penanaman dua siklus. Media tanam yang telah digunakan sebanyak dua kali yang merupakan limbah diolah kembali untuk menjadi pupuk kompos. Pengomposan dilakukan dengan cara yang sama seperti pengomposan media tanam namun untuk jangka waktu yang lebih lama sampai limbah media tanam tersebut berubah menjadi pupuk kompos.

11. Setelah semua kegiatan selesai dilakukan, maka selanjutnya dilakukan pemantauan atau evaluasi untuk mengetahui:

- Apakah proses budidaya jamur merang petani mitra berjalan dengan baik.

- Apakah proses pemasaran jamur merang berjalan dengan lancar

- Apakah petani mitra ada melakukan pengolahan limbah media tanam menjadi pupuk kompos

- Apakah pupuk kompos yang mereka hasilkan mereka pasarkan untuk menambah penghasilan

- Bagaimana respon masyarakat terhadap kegiatan ini

Kegiatan pengabdian memiliki beberapa luaran yang merupakan manfaat yang didapatkan selama proses pengabdian berlangsung. Keluaran yang didapatkan dari kegiatan ini adalah peningkatan aset, omset, pengetahuan, dan ketrampilan petani. Selain itu, keluaran lainnya berupa publikasi dan buku ajar.

\section{KESIMPULAN DAN SARAN}

\section{Kesimpulan}

Pengabdian IbM Penerapan Bioteknologi dan Pengolahan Limbah Media Tanam Jamur Merang di Kecamatan Nisam Kabupaten Aceh Utara berjalan sesuai dengan yang diharapkan. Semua kegiatan, kecuali pembibitan telah berhasil dijalankan dengan baik. Hal ini terjadi berkat kerjasama tim pengabdian dan dukungan universitas yang baik serta peran aktif dari petani mitra.

\section{Saran}

Hasil yang didapatkan dari usahatani jamur yang saat ini belum mampu mencukupi kebutuhan seluruh anggota kelompok. Hal ini disebabkan oleh jumlah kumbung yang belum memadai, yaitu dua kumbung yang dikelola oleh 10 orang. Oleh karena itu, penambahan jumlah kumbung sangat diperlukan.

\section{DAFTAR PUSTAKA}

Asep, 2013, Budidaya Jamur Merang, http://asevha.blogspot.com/2013/03/budidayajamur merang.html, 29 April 2016. 
Sinaga, M.S, 2015, Budidaya Jamur Merang, Edisi Ketiga, Penebar Swadaya: Jakarta.

Sunarmi, Y.I, dan S. Cahyo, 2013, Usaha 6 Jenis Jamur Skala Rumah Tangga, Edisi Keempat, Penebar Swadaya: Jakarta.

Tassan, Sugito, 2016, Petani Jamur Merang Kesulitan Cari Bibit. http://www.medanbisnisdaily.com/news/read/2016/01/06/208155/petanijamurmeran g-kesulitan-cari-bibit/, 29 April 2016.

Una, 2016, Permintaan Jamur Merang Meningkat, http://aceh.tribunnews.com/2016/01/14 /permintaan-jamur-merang-meningkat, 29 April 2016.

Wiardani, I, 2010, Budidaya Jamur Konsumsi, Andi: Jakarta. 